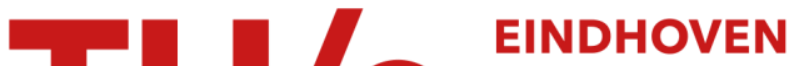 UNIVERSITY OF TECHNOLOGY
}

\section{Investigation of local degradation in wood stands and its effect on cement wood composites}

\section{Citation for published version (APA):}

Kochova, K., Caprai, V., Gauvin, F., Schollbach, K., \& Brouwers, H. J. H. (2020). Investigation of local degradation in wood stands and its effect on cement wood composites. Construction and Building Materials, 231, [117201]. https://doi.org/10.1016/j.conbuildmat.2019.117201

\section{Document license:}

TAVERNE

DOI:

10.1016/j.conbuildmat.2019.117201

Document status and date:

Published: 20/01/2020

\section{Document Version:}

Publisher's PDF, also known as Version of Record (includes final page, issue and volume numbers)

\section{Please check the document version of this publication:}

- A submitted manuscript is the version of the article upon submission and before peer-review. There can be important differences between the submitted version and the official published version of record. People interested in the research are advised to contact the author for the final version of the publication, or visit the $\mathrm{DOI}$ to the publisher's website.

- The final author version and the galley proof are versions of the publication after peer review.

- The final published version features the final layout of the paper including the volume, issue and page numbers.

Link to publication

\section{General rights}

Copyright and moral rights for the publications made accessible in the public portal are retained by the authors and/or other copyright owners and it is a condition of accessing publications that users recognise and abide by the legal requirements associated with these rights.

- Users may download and print one copy of any publication from the public portal for the purpose of private study or research.

- You may not further distribute the material or use it for any profit-making activity or commercial gain

- You may freely distribute the URL identifying the publication in the public portal.

If the publication is distributed under the terms of Article 25fa of the Dutch Copyright Act, indicated by the "Taverne" license above, please follow below link for the End User Agreement:

www.tue.nl/taverne

Take down policy

If you believe that this document breaches copyright please contact us at:

openaccess@tue.nl

providing details and we will investigate your claim. 


\title{
Investigation of local degradation in wood stands and its effect on cement wood composites
}

\author{
K. Kochova*, V. Caprai, F. Gauvin, K. Schollbach, H.J.H. Brouwers \\ Department of the Built Environment, Eindhoven University of Technology, P.O. Box 513, 5600 MB Eindhoven, the Netherlands
}

H I G H L I G H T S

- Two very similar types of wood (A and B) are used in WWCB in this study.

- WWCBs made with Wood B do not fulfil the flexural strength standards.

- Wood B has some compatibility issue with the cement, with CX'<80.

- Degradation of Wood B is only characterized close to the pits.

- Chemical analyses confirm the local hemicellulose degradation.

\section{A R T I C L E I N F O}

\section{Article history:}

Received 4 April 2019

Received in revised form 3 October 2019

Accepted 8 October 2019

\section{Keywords:}

Wood-wool cement boards

Cement-fibre compatibility

Calorimetry

SEM

Leachates

\begin{abstract}
A B S T R A C T
Wood-wool cement boards (WWCB) are a type of cement/fibre composite using wood strands as reinforcement. When lignocellulosic materials such as wood are mixed with cement, polysaccharides can leach out and negatively affect the cement hydration. Thus, the WWCB industry has to face those problems, which can cause significant problems during the manufacturing process. This study aims to identify the parameters that can influence the quality of wood and thus the WWCB. The investigation focuses on the potential differences between these two wood samples, by analysing the cement/wood compatibility, the mechanical properties of the wood strands, the microstructure and the chemical composition of the leachates. Two similar spruce wood samples, which have been grown and harvested under the same conditions are compared to each other. When mixed with cement, one sample performed up to expectation in WWCB whereas the second one shows chemical and mechanical problems, resulting in weak WWCBs that cannot fulfil the standards. A comparison two wood samples shows not only different properties of WWCB. Cement-fibre compatibility for one of the sample is below the limit to be used in composite and tensile strength shows a similar behaviour.
\end{abstract}

(c) 2019 Elsevier Ltd. All rights reserved.

\section{Introduction}

In the last decade, the application of wood-cement composites has grown, especially for thermal or acoustic insulation purposes $[1,2]$. The popularity of this building material is mainly related to the increasing concerns about sustainability in the building industry [3]: Natural fibres are not expensive and have lightweight, nontoxic and biodegradable properties which lead to many applications as replacement of synthetic fibres [4]. One commonly used composite is the wood wool cement board (also called Excelsior board, WWCB), produced using Spruce (Picea Abis) wood wool strands, white cement and chemical additives and characterized by a high wood/cement ratio (0.4-0.6) $[1,5,6]$. Having a thickness

\footnotetext{
* Corresponding author.

E-mail address: kochkatka@hotmail.com (K. Kochova).
}

between 50 and $150 \mathrm{~mm}$, WWCBs are mainly applied as ceiling tiles for acoustic insulation, but they also have good acoustic properties and durability against fungi thanks to the fibre mineralization $[1,2,7]$. Their density ranges between 300 and $500 \mathrm{~kg} / \mathrm{m}^{3}$, leading to a flexural strength lower than $10 \mathrm{MPa}$, depending on the slab thickness $[5,6]$. Due to the numerous critical factors affecting the wood quality, WWCB production has to take several aspects into account, during the board manufacture: Geometry and mechanical strength of the wood strand, their water adsorption, wood/cement ratio and general wood cement compatibility [8]. Among the influencing factors, low wood cement compatibility plays a significant role in WWCB performances [9]. The presence of leachable extractives is known to delay the cement hydration, leading to low strength of the composites [10-12]. For these reasons, industrial WWCB production relies mostly on conifers such as pines or spruce wood from commercial forests [13], 
characterized by a minimal presence of leachable extractives $[8,10,17]$. Moreover, after felling, the trunk is cleaned from the bark and stored as logs for 6-12 month, to reduce the moisture content and to limit the presence of those extractives [10,13]. Consistent moisture content and water adsorption of the wood are important aspects, because cement requires a specific water/cement ratio in order to hydrate and provide adequate strength, typically $0.35-$ $0.5[5,6]$. If the moisture content of wood is too high, it can release the water and increase the effective water/cement ratio, leading to a porous binder with low strength $[5,15]$. It is also possible that the wood absorbs too much water needed for the hydration of cement. In that case, part of the cement cannot hydrate, also leads to low strength of the composite [5,14].

Even if these factors are taken into account, wood is a natural material, and its properties can vary even within the same species $[8,16]$. Therefore, consistent and strict quality control is essential prior to composite manufacture. Yet, even with this assessment, some batches of wood can perform poorly in WWCB. It leads to defective boards with either insufficient flexural strength (minimum required by the standard BS EN 12089-1.7 MPa [18]) or swelling/loss of cohesion of the boards after demoulding. The reasons for these failures are still poorly understood and few studies about bad quality wood and its effects on the overall performances of WWCB exist.

This study focuses on two different wood samples, named wood $A$ and $\operatorname{wood} B$, in order to investigate their effect on WWCB. The batches of spruce wood were grown and cut in the same European location, and one of these two batches (B) resulted in low quality during the industrial manufacture of WWCBs, even though it passed quality controls. First, WWCBs are manufactured with these two types of wood in order to compare their flexural strength and density. Then, the wood strands are mixed with white cement and by using isothermal calorimetry; the compatibility of the two types of wood with cement is assessed. After that, the mechanical strength of individual wood strands is tested to determine the influence of wood quality on the fibre and board performances. Microscopy at the wood surface but also inside the pores aims to confirm the previous observations. Finally, wood leachates are prepared and analysed by anion exchange chromatography in order to compare their concentration of polysaccharides.

\section{Materials and methods}

\subsection{Materials}

Two types of spruce wood wool were collected from an industrial manufacturer of WWCBs and are named wood A and wood $B$ in this study. The wood wool is approximately $1-3 \mathrm{~mm}$ in width, $0.1-0.5$ in thickness and $25 \mathrm{~cm}$ in length [13]. The average chemical composition of the spruce fibres is given in Table 1 . White cement CEM I $52.5 \mathrm{R}$ from ENCI, the Netherlands, is used as a binder and its chemical composition is given in Table 2.

\subsection{Methods}

\subsubsection{Manufacture of the composite}

Wood wool cement composites are manufactured based on the dry method, commonly applied by composite manufacturers. The

\section{Table 1}

Spruce wood strands chemical composition as measured in a previous study [10].

\begin{tabular}{ll}
\hline Chemical composition & {$[\%]$} \\
\hline Cellulose & $41.6 \pm 0.1$ \\
Hemicellulose & $37.36 \pm 1.1$ \\
Lignin & $19.46 \pm 1.1$ \\
\hline
\end{tabular}

Table 2

Chemical composition of white cement CEM I 52.5R white used in this study.

\begin{tabular}{ll}
\hline Chemical composition & {$[\%]$} \\
\hline $\mathrm{CaO}$ & 62.21 \\
$\mathrm{SiO}_{2}$ & 20.93 \\
$\mathrm{Al}_{2} \mathrm{O}_{3}$ & 3.90 \\
$\mathrm{Fe}_{2} \mathrm{O}_{3}$ & 0.45 \\
$\mathrm{~K}_{2} \mathrm{O}$ & 0.12 \\
$\mathrm{Na}_{2} \mathrm{O}$ & 0.11 \\
$\mathrm{SO}_{3}$ & 2.92 \\
$\mathrm{MgO}_{\mathrm{TiO}}$ & 0.43 \\
$\mathrm{Mn}_{3} \mathrm{O}_{4}$ & 0.33 \\
$\mathrm{P}_{2} \mathrm{O}_{5}$ & 0.02 \\
\hline
\end{tabular}

spruce strands (1-3 mm in width, 0.1-0.5 in thickness and $25 \mathrm{~cm}$ in length) are pre-soaked with water until they reach a certain moisture content, and thereafter dry binder is sprinkled on them. After mixing, the wood-binder mixture is placed in a mould $(30 \times 20 \times 1.5 \mathrm{~cm})$ and pressed for $24 \mathrm{~h}$, under a mechanical press. Afterwards, the board is cured in plastic sheets for seven days and left at ambient conditions for three days. Finally, the board is dried at $50{ }^{\circ} \mathrm{C}$ for $2 \mathrm{~h}$ prior to mechanical testing. The water to binder ratio used in this study is 0.5 , while the wood to binder ratio is 0.75 .

\subsubsection{Mechanical performances}

Mechanical performances of the WWCB are tested by threepoint bending test (Zwick 2020) following the BS EN 12089, Thermal insulating products for building applications standard on a sample $20 \times 15 \times 1.5 \mathrm{~cm}$, using a testing speed of $1.5 \mathrm{~mm} / \mathrm{min}$ and a support span of $15 \mathrm{~cm}$ (method A) [18]. As reference values, the standard indicates that a board is acceptable with a maximum thickness of $1.5 \mathrm{~cm}$, a minimum bending strength of $1.7 \mathrm{MPa}$ and a density of $500-600 \mathrm{~kg} / \mathrm{m}^{3}$.

\subsubsection{Isothermal calorimetry}

Isothermal calorimetry is performed by using a TAM Air Isothermal calorimeter at a constant temperature of $20^{\circ} \mathrm{C}$. Fibres with a particle size of 2-4 $\mathrm{mm}$ are mixed with cement and water. The water/cement ratio is kept constant for all prepared mixes $(\mathrm{w} /$ $c=0.45$ ) and the fibre/cement ratio is 0.075 . After mixing, the samples are placed in the calorimeter with large cup holder (i.e. $40 \mathrm{~g}$ of materials can be tested) to observe and determine the cement hydration behaviour.

\subsubsection{Compatibility}

In this study, an equation by Pasca et al. [19] is used to assess the compatibility CX' between wood fibres and cement. The equation is developed for cement-wood compatibility and it used cement/wood/water mixtures to calculate the compatibility.

The CX' factor can be determined using equation [20]:

$\mathrm{CX}^{\prime}=\sqrt[3]{\left(\frac{\mathrm{HR} \max * \mathrm{HR} 3.5-24 * \mathrm{t}^{\prime} \max }{\mathrm{HR}^{\prime} \max * \mathrm{HR}^{\prime} 3.5-24 * \mathrm{tmax}}\right) * 100}$

where HR' $_{\text {max }}$ is the maximum heat rate of cement wood mixtures; $\mathrm{HR}_{3.5-24}$ is the total heat released by cement wood mixtures in its hydration period $(3.5-24 \mathrm{~h}) ; t_{\max }$ is the time to reach maximum heat rate of cement mixtures; $\mathrm{HR}_{\text {max }}$ is the maximum heat rate of neat cement mixtures; $\mathrm{HR}^{\prime}{ }_{3.5-24}$ is the total heat released by neat cement mixtures in the hydration period; $t_{\text {max }}^{\prime}$ is the time to reach maximum heat rate of neat cement mixtures. All the calculations were based on the mass of the mixture. Three groups can be defined in order to make a classification of cement-fibre compatibility: 
Incompatibility: $\mathrm{CX}^{\prime}<40$; moderate compatibility: $40 \leq \mathrm{CX}^{\prime} \leq 80$; compatibility: $\mathrm{CX}^{\prime}>80$.

\subsubsection{Tensile properties of wood strands}

Mechanical properties of wood strands are measured by using an Instron 5967 bench equipped with a $2530-100 \mathrm{~N}$ load cell and 2710-111 wedge grip with rubber jaw faces. Tensile tests are conducted in displacement control with a crosshead speed of $5 \mathrm{~mm} /$ min. More than 15 samples are tested. Tensile strength $(\mathrm{cN} /$ tex $)$ and Young's modulus (N/tex) are measured as a function of the linear density of the fibre (tex) by measuring the length and the weight of each fibre prior to analysis.

\subsubsection{Scanning electron microscopy}

SEM analyses are performed by using an FEI quanta 600 environmental scanning electron microscope to observe the surface and the cross-section of the wood. Micrographs are recorded by using both secondary and backscattering electrons detectors at $10 \mathrm{kV}$ with a spot of 4 , in low vacuum mode ( 0.6 mbar).

\subsubsection{Leachate preparation}

Wood samples are dried at $60{ }^{\circ} \mathrm{C}$ to constant mass and soaked for $2 \mathrm{~h}$ at $100{ }^{\circ} \mathrm{C}$ in distilled water (water/fibres ratio $=5: 1$ ). Filtrate and fibres are separated with filter paper. The $\mathrm{pH}$ of the fibre leachates is measured by a pH Meter (Metrohm 780) at room temperature.

\subsubsection{The concentration of monomeric sugars and uronic acids}

The concentration of the monomeric sugars of the different leachate solutions is determined by high-performance anion exchange chromatography (HPAEC) after $\mathrm{H}_{2} \mathrm{SO}_{4}$ hydrolysis. The solution is freeze-dried (1-4 $\mathrm{ml}$ of leachates) and vigorously mixed in Pyrex test tubes with $150 \mu \mathrm{l}$ of ice-cold $\mathrm{H}_{2} \mathrm{SO}_{4}\left(12 \mathrm{~mol} \cdot \mathrm{L}^{-1}\right)$ in a water bath at $30{ }^{\circ} \mathrm{C}$ for one hour. Samples are then removed from the water bath and mixed with an $\mathrm{H}_{2} \mathrm{SO}_{4}$ (4\%) solution. Samples are then placed in an autoclave for $60 \mathrm{~min}$ at $120^{\circ} \mathrm{C}$. After being cooled down, $5 \mathrm{mg}$ of ribose is added to each sample as an internal standard. Hydrolysed leachates are diluted with deionized water at a different ratio (from 1:10 to 1:100) prior to analysis. Measurements are done with a Thermo Scientific Dionex ICS-5000 system. Samples are separated on a Dionex CarboPac PA1 carbohydrate column.

The concentration of uronic acids is then measured by gas chromatography (GC) after methanolysis according to Sundberg [21]. Samples are lyophilized and then hydrolysed in $2 \mathrm{M}$ methanolic $\mathrm{HCl}$ at $100^{\circ} \mathrm{C}$ for $5 \mathrm{~h}$, followed by addition of pyridine and sorbitol as an internal standard at room temperature. After evaporation under $\mathrm{N}_{2}$, samples are silylated overnight with HMDS (hexamethyldisilazane, Sigma-Aldrich) and TMCS (trimethyl-chlorsilan, Sigma-Aldrich) in pyridine, injected into a GC/FID system (7890A, Agilent Technologies) at $260^{\circ} \mathrm{C}$, and separated on an HP-5 column ( $30 \mathrm{~m}, 0.32 \mathrm{~mm}$ ID, $0.25 \mu \mathrm{m}$ film thickness) using the following temperature program: $150^{\circ} \mathrm{C}$ for $1 \mathrm{~min}, 150^{\circ} \mathrm{C}$ to $220^{\circ} \mathrm{C}$ at $4{ }^{\circ} \mathrm{C} /$ $\min , 220^{\circ} \mathrm{C}$ to $320^{\circ} \mathrm{C}$ at $20^{\circ} \mathrm{C} / \mathrm{min}, 320^{\circ} \mathrm{C}$ for $6.5 \mathrm{~min}$. Calibration of peak areas is done using identically treated authentic standards of D-glucuronic and $\mathrm{D}(+)$-galacturonic acids.

\section{Results and discussion}

\subsection{Mechanical performances of the wood wool composites}

The WWCB mechanical performances are displayed in Fig. 1, together with the relative board density. It appears that their flexural properties are significantly different. Wood A surpasses Wood B by three time, reaching almost five MPa in flexural strength.
Moreover, due to the low performance of WWCB, Wood B does not fulfil the minimum requirements necessary for boards $1.5 \mathrm{~cm}$ thick [22] and are therefore not eligible for application.

Since the WWCBs have been manufactured using the same recipe and therefore have a very similar moisture content, the difference in performance cannot be related to the different water availability for the binder reaction [5]. The density of boards made with Wood A is also slightly above WWCB made with Wood B, but this difference is very small and cannot be explained such big differences between the two WWCBs.

\subsection{Cement fibre interaction}

Fig. 2a and b depict the isothermal calorimetry measurements of the effect of the two types of spruce wood on the cement hydration. The heat flow and released heat are normalised to the mass of cement. Addition of Wood A to the cement paste slightly decreases the heat flow and slows down the cement hydration. However, as can be seen in Fig. 2a, Wood B has a much greater effect on the heat flow as well as on the released heat (Fig. 2b). The maximum peak of the cement hydration is slowed down by $1 \mathrm{~h}$ with the addition of Wood A and more than $2 \mathrm{~h}$ with Wood B. From Fig. $2 \mathrm{~b}$ it can be seen a difference of total cumulative released heat during the exothermic reaction of cement while it is mixed with water/leachates. The difference between reference sample and Wood A is minor. On the other hand, a big difference is seen between reference sample and Wood B. This phenomenon can be explained with the fact that wood has extractives which can hinder or stop the cement hydration by interacting with the cement and the hydration products [8]. Based on the Fig. $2 \mathrm{a}$ and $\mathrm{b}$, it can be assumed that Wood B contains more inhibitors than Wood A.

By using Pasca's equation and isothermal calorimetry measurements (Fig. 2a), the cement-fibre compatibility is calculated for these two samples. (Table 3). From these results, Wood A is compatible (85) whereas Wood B is moderately compatible (75) with cement which supports the observations shown in Fig. 2a and b. However, this slight decrease in compatibility cannot be the only reason for the big difference seen with WWCB flexural strengths.

\subsection{Characterization of wood fibres}

The tensile strength of individual wood strands has been measured in order to evaluate if the quality of wood can be assessed from its smallest unit, which in the case of wood-wool cement board corresponds to one strand. The two types of wood have been tested and the average results of tensile strength and E-modulus are shown in Table 4 and a characteristic stress/strain curve is also shown in Fig. 3.

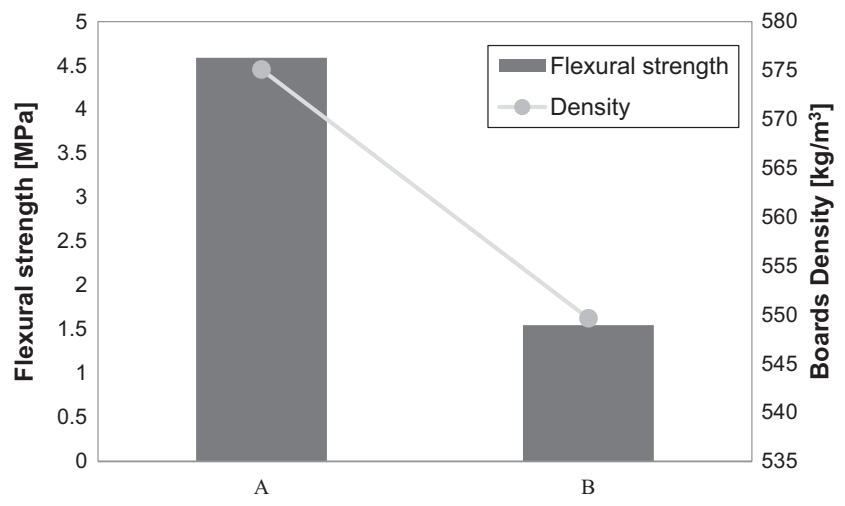

Fig. 1. Flexural strength comparison of WWCBs manufactured with the Wood A and the Wood B. 


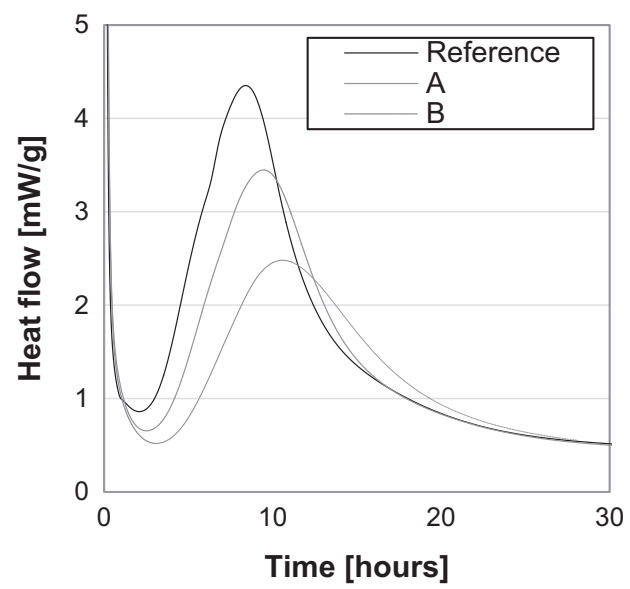

(a)

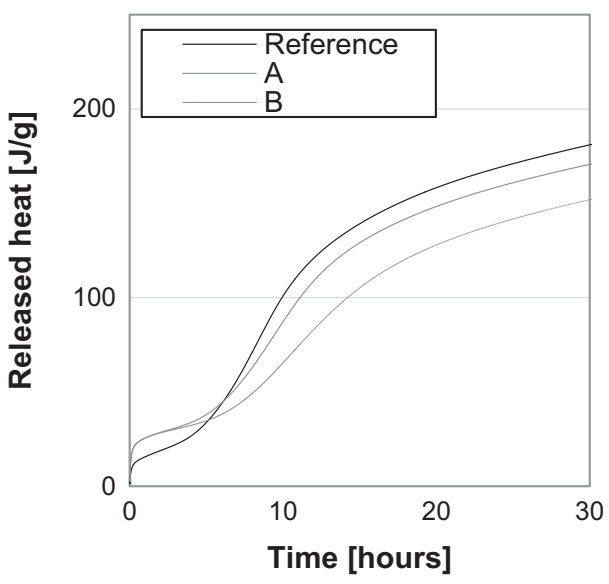

(b)

Fig. 2. Effect of the Wood A and the Wood B on the cement hydration of OPC paste at $20^{\circ} \mathrm{C}$ : a) Heat flow, b) Released heat.

Table 3

Cement-fibre compatibility of white cement CEM I 52.5R and wood samples.

\begin{tabular}{ll}
\hline Wood & Cement-fibre compatibility \\
\hline$A$ & 85 \\
$B$ & 75 \\
\hline
\end{tabular}

Table 4

Average value of the tensile modulus and the tensile strength of the tested wood strands.

\begin{tabular}{lll}
\hline Wood & Modulus [N/tex] & Tensile strength [cN/tex] \\
\hline$A$ & $1645 \pm 349$ & $1316 \pm 437$ \\
$B$ & $1011 \pm 363$ & $512 \pm 173$ \\
\hline
\end{tabular}

Results show significant differences between the two types of wood. Wood A has a tensile strength two and half times higher than that of Wood B (+157\%). It has to be pointed out that the standard deviation of the test is quite high, which is common with heterogeneous cellulosic fibres. Still, statistically, the lowest tensile strength value of Wood A is higher than the highest one of Wood B. The tensile moduli of the strands have also been studied and similarly, Wood A shows greater values $(+63 \%)$ than Wood B, even though in this case, considering the high standard deviation, this difference is not very significant.

These decrease in tensile strength means that the microstructure of the wood itself was affected prior to wood strand production. Wood consists primarily of cellulose, hemicellulose and lignin (Table 1) [10]. In this study, it appears that the tensile moduli of the two types of wood (A and B) are sensibly the same. In composite materials, intrinsic properties such as the tensile modulus are defined by the rule of mixtures [23]. In lignocellulosic material such as wood, the intrinsic mechanical properties are coming from the cellulose fibrils, located inside the hemicellulose and lignin matrix [24]. Therefore, this result indicates that cellulose has not been affected by internal degradation. As compared to the tensile modulus, the tensile strength of the fibres is not only defined by the cellulose fibrils and the rule of mixtures but also by the quality of the interface and the load transfer assured by the matrix.

A probable hypothesis would be that the lignin or the hemicellulose have been slightly degraded during the wood storage. This degradation has a negligible effect on the bulk wood properties but when cut into strands, this effect is much more noticeable. In order to demonstrate this theory, microstructure analyses are done by SEM.

Fig. 4 shows the micrographs of the surface and the transverse section of Wood A and B strands. The surface of Wood A strand is

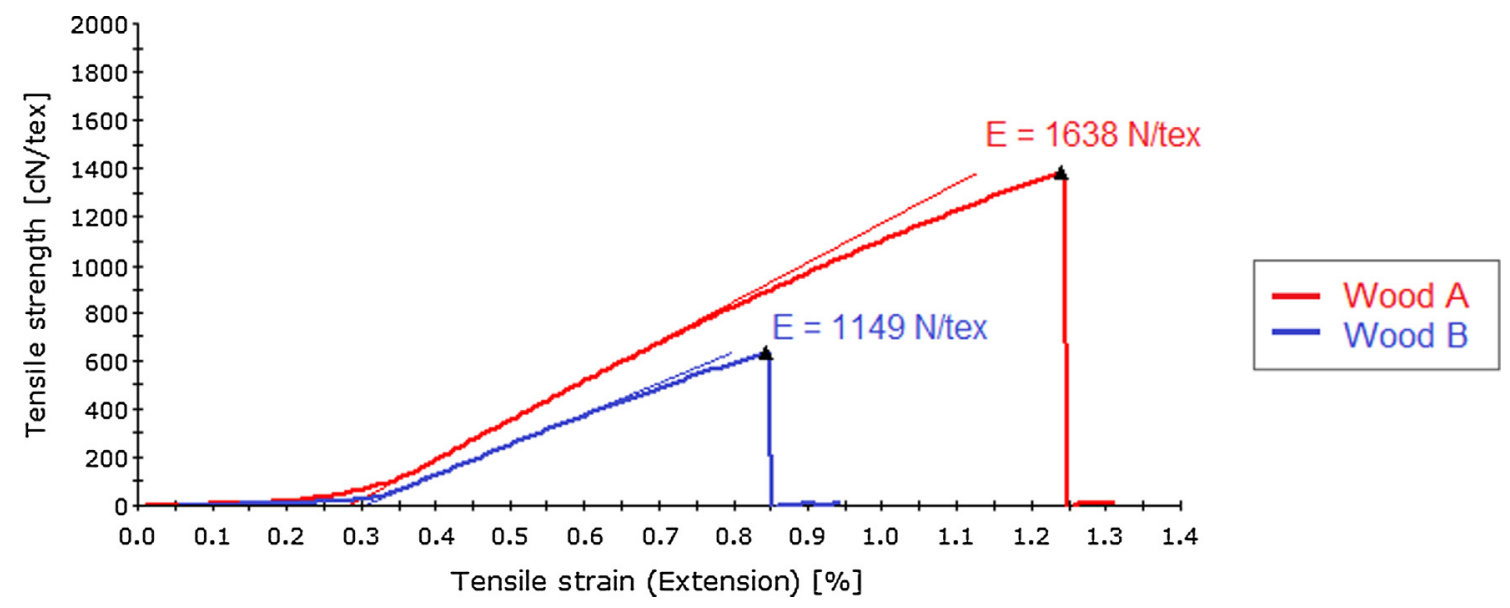

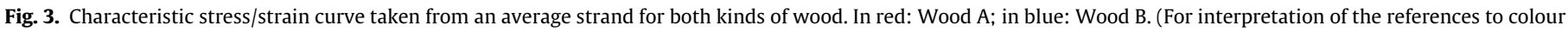
in this figure legend, the reader is referred to the web version of this article.) 

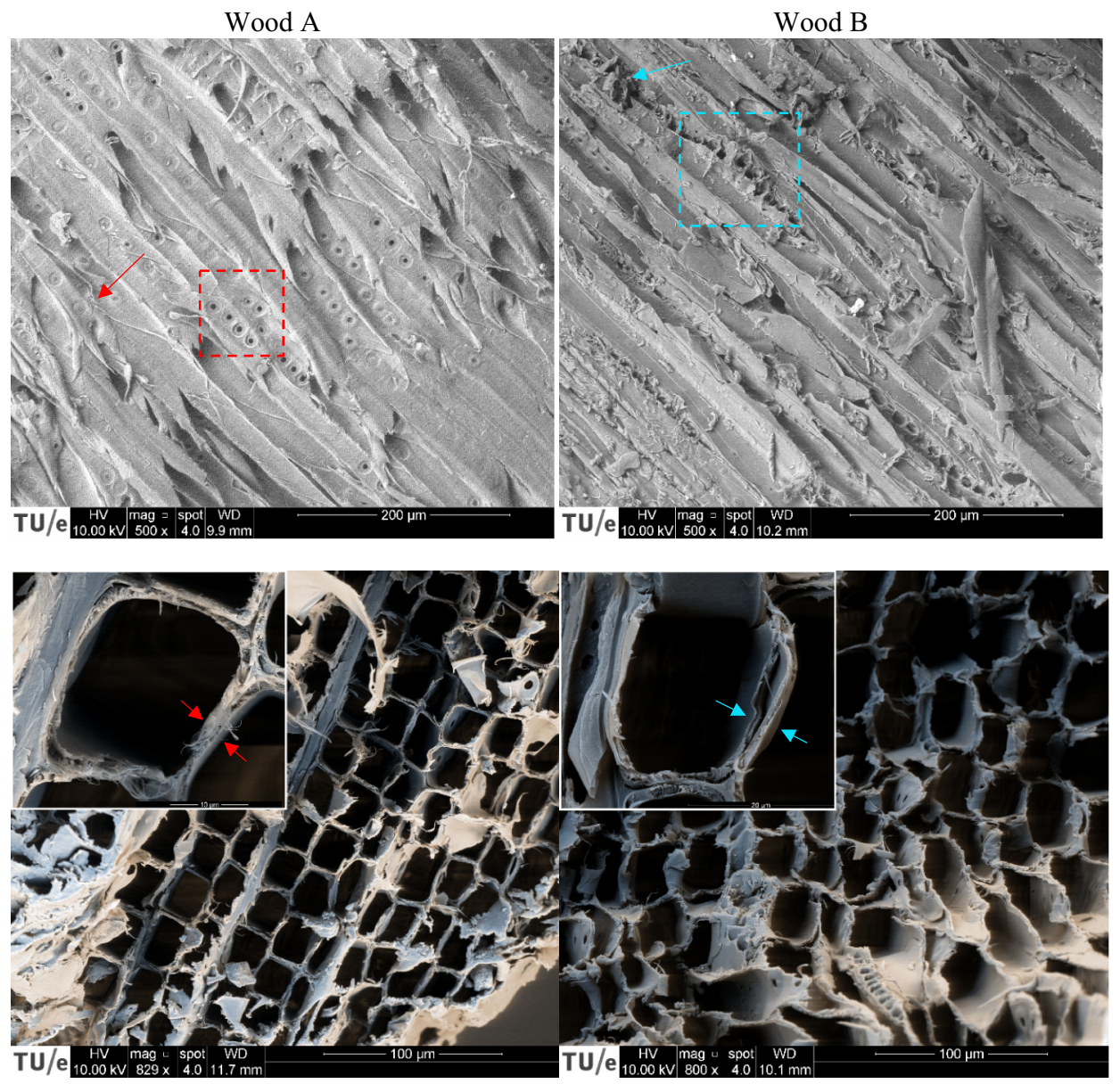

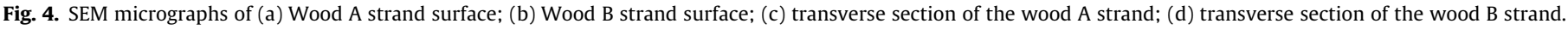

very similar to the available literature about spruce wood, where pits are easily observable and aligned along the fibre (red box) [25]. The matrix is uniformly dispersed at the surface (red arrow), covering the whole surface and overlapping at the border of the pits (Fig. 4a). However, as seen in Fig. 4b, the surface of Wood B is different. The matrix seems less smooth but more importantly, the pits are not well defined (blue box) and seem damaged (blue arrow). From the literature, this phenomenon looks like a brownrot fungi bio-degradation, with fungal hyphae coming out of the pits [26]. However, in this case, the degradation seems even more pronounced and a close up of the pit shows that the matrix is completely destroyed and the fungi degradation is not clearly observable. The transverse section micrographs of Wood A and B are shown in Fig. 4c and $d$ and both wood fibres have a very similar structure (red and blue arrows). Cell walls are well defined and the only noticeable differences are mostly due to the sample preparation. As compared to some studies showing the transverse section of the different type of woods which have been degraded, the wood cells here, in both case, seem to be intact with no visible shrinkage or distortion [27]. Moreover, no fungal hyphae are observable in both cases.

From these observations, several conclusions can be drawn. First, Wood A seems to be intact. There are no traces of any kind of degradation; neither at the surface nor inside the cells and the micrographs are very similar to the conventional spruce characterized in the literature. On the other hand, Wood B has been locally degraded, close to the surface pits, and this degradation is quite important. Nevertheless, even though Wood B has been degraded, this phenomenon was not visible in the cross section, where the cellulose fibrils are located. It would explain the mechanical behaviour of Wood B, with a strength decrease (i.e. local destruction of the hemicellulose/lignin matrix leading to an important stress concentration factor) but a relatively unchanged modulus (i.e. cellulose fibrils, with high tensile modulus, have not been damaged) as compared to Wood A.

\subsection{Chemical characterization of wood leachates}

The leachates of the two wood types are analysed in order to evaluate the link between the organic inhibitors that can be contained in wood, the compatibility and low mechanical strength of the WWCB as characterized in the previous sections. Five monomeric sugars are measured, arabinose, galactose, glucose, xylose and mannose (Table 5), which are the main hydrolysis products of cellulose and hemicellulose [28]. In overall, Wood B has much higher sugar content than Wood A. A correlation can be observed between the released heat during the first $30 \mathrm{~h}$ of cement hydration (Fig. 2b) and the total amount of sugars (Table 5), where a high amount of sugars leads to a lower released heat.

From the literature, it is known that the most problematic effect caused by monomeric sugars is mostly caused by glucose due to a disruption of C-S-H gel formations [29]. In this study, among the characterized polysaccharides, glucose is six times higher in Wood B than Wood A. But any polysaccharides can cause the nucleation poisoning of hydrate surfaces and thus can affect the retardation mechanism based on the absorption of the clinker gains [8]. For instance, xylose is also characterized to be problematic [17] and the amount of xylose is nine times higher in Wood B. Mannose is 
Table 5

Comparison of Wood A and Wood B extractives measured by HPAEC after $\mathrm{H}_{2} \mathrm{SO}_{4}$ hydrolysis.

\begin{tabular}{|c|c|c|c|c|c|c|}
\hline Wood & $\begin{array}{l}\text { Arabinose } \\
\mathrm{mcg} / \mathrm{ml}\end{array}$ & $\begin{array}{l}\text { Galactose } \\
\mathrm{mcg} / \mathrm{ml}\end{array}$ & $\begin{array}{l}\text { Glucose } \\
\mathrm{mcg} / \mathrm{ml}\end{array}$ & $\begin{array}{l}\text { Xylose } \\
\mathrm{mcg} / \mathrm{ml}\end{array}$ & $\begin{array}{l}\text { Mannose } \\
\mathrm{mcg} / \mathrm{ml}\end{array}$ & $\begin{array}{l}\text { Total Sugars } \\
\mathrm{mcg} / \mathrm{ml}\end{array}$ \\
\hline A & 19.8 & 82.6 & 15.2 & 3.1 & 29.5 & 150.2 \\
\hline$B$ & 23.4 & 83.3 & 91.3 & 28.9 & 182.7 & 409.6 \\
\hline
\end{tabular}

Table 6

Quantification of uronic acids measured by CG after methanolysis, as well as the $\mathrm{pH}$ value of the leachates.

\begin{tabular}{llll}
\hline Wood & $\begin{array}{l}\text { Galacturonic acid } \\
\mathrm{mcg} / \mathrm{ml}\end{array}$ & $\begin{array}{l}\text { Glucuronic acid } \\
\mathrm{mcg} / \mathrm{ml}\end{array}$ & $\mathrm{pH}$ \\
\hline$A$ & 4.4 & 17.9 & 5.9 \\
$B$ & 27.9 & 24.5 & 5.4 \\
\hline
\end{tabular}

also leached out from Wood B and in the literature, it is shown that the hemicellulose may complex with metal ions in cement through mannose hydroxyls and then decrease crystallinity, hydration rate and strength [17].

Alongside monomeric sugars, uronic acids are also known to have a retarder effect on cement hydration. In this study, two types of uronic acid are measured, namely galacturonic acid (GAA) and glucuronic acid (GLA). Both acids are derived from monomeric sugars, GAA is from galactose and GLA is from glucose [30]. Table 6 depicts the concentration of GAA and GLA in the fibre leachates and shows the value of the $\mathrm{pH}$ of the leachates. As expected, the concentration of uronic acids is higher with Wood B. If monomeric sugars can cause a significant delay to the cement hydration due to their degradation products, the $\mathrm{pH}$ of the cement during the hydration phase is also a critical factor and may be affected by the numerous carboxylic acids leached by cellulosic fibres $[15,16]$.

In overall, results show Wood B is affected by the degradation of hemicellulose. Measurement of the leachates shows that the high concentration of polysaccharides (e.g. Glucose, mannose and xylose) and uronic acids in Wood B are direct results from the hydrolysis of the hemicellulose. However, this significant increase in polysaccharide concentration does not affect the wood/cement compatibility too much $\left(\mathrm{CX}^{\prime}=85\right.$ and 75 for Woods $\mathrm{A}$ and $\mathrm{B}$, respectively). It can be explained by the confined degradation, which only happens close to the pits, limiting the diffusion of polysaccharides to the cement matrix.

\section{Conclusion}

This study aims to point out the difference between two very similar, commercially produced spruce wood wool fibre batches. Results show that even though these two types of wood passed standard quality controls, they are significantly different in terms of compatibility, mechanical properties and microstructure. The following conclusions can be drawn:

- WWCBs are made with the two types of wood. Wood A gives satisfactory results, far above the acceptable limit (i.e. $1.7 \mathrm{MPa}$ ) whereas the strength of Wood B is significantly lower and cannot fulfil the requirement. This major difference confirms the eminent difference between these two wood.

- Cement-fibre compatibility is calculated and Wood B is slightly less compatible than Wood A, which is considered to be compatible $\left(C X^{\prime}=85\right)$, while Wood $B$ is considered moderately compatible $\left(C X^{\prime}=75\right)$ with cement, and it is one of the reasons why Wood B resulted in low-quality WWCB.

- Mechanical characterization of the strands shows that Wood B is clearly damaged as its strength is significantly lower than Wood A (-63\%). Microscopy shows clear damage close to the pit, but not in the cell walls, explaining a possible matrix (i.e. hemicellulose) degradation. On the other hand, the cellulose seems untouched, as it can be seen with the unchanged Emodulus between Wood A and B.

- Wood leachates are prepared from Wood A and B and the polysaccharides and acid measurements confirm the previous observations. The degradation of hemicellulose causes an increasing amount of GAA, glucose, mannose and xylose in the fibre. This degradation could be the result of fungi attack.

In overall, this study indicates that current quality control methods are not suitable to characterize micro degradation that can have a significant effect on the WWCB properties. From these results, cement/fibre compatibility and single strand tensile tests are good indicators of degradation. Thus, on an industrial scale, these methods could be used in the future in order to improve the existing quality controls of the wood prior to the manufacture of WWCB.

\section{Declaration of Competing Interest}

The authors declare that they have no known competing financial interests or personal relationships that could have appeared to influence the work reported in this paper.

\section{Acknowledgements}

The authors would like to acknowledge the financial support provided by NWO (Nederlandse Organisatie voor Wetenschappelijk Onderzoek), the Netherlands, under the project number 10013077, entitled: "Development of sustainable and functionalizes inorganic binder-biofibres composites”.

\section{References}

[1] G.C.H. Doudart de la Grée, Q.L. Yu, H.J.H. Brouwers, Wood-wool cement board: potential and challenges, Int. Inorganic-Bonded Fiber Compos Conf. 154-164 (2014). http://purl.tue.nl/449247297565249.pdf.

[2] A. Ashori, T. Tabarsa, K. Azizi, R. Mirzabeygi, Wood-wool cement board using mixture of eucalypt and poplar, Ind. Crops Prod. 34 (2011) 1146-1149, https:// doi.org/10.1016/j.indcrop.2011.03.033.

[3] M. Rafikul Islam, F. Rahman, M. Nazrul Islam, M. Nasim Rana, S. Kumar Nath, M. Ashaduzzaman, M. Iftekhar, Cement-Bonded Lignocellulosic Panel (CLP): A Promising Environmental Friendly Construction Material for Conservation of Forest Resources, (n.d.). doi: 10.1007/978-3-319-48281-1_178-1.

[4] S. Kalia, B.S. Kaith, I. Kaur, Pretreatments of natural fibers and their application as reinforcing material in polymer composites-a review, Polym. Eng. Sci. (2009), https://doi.org/10.1002/pen.21328.

[5] V. Caprai, F. Gauvin, K. Schollbach, H.J.H. Brouwers, Influence of the spruce strands hygroscopic behaviour on the performances of wood-cement composites, Constr. Build. Mater. 166 (2018) 522-530, https://doi.org/ 10.1016/j.conbuildmat.2018.01.162.

[6] R.W. Wolfe, A. Gjinolli, Cement-Bonded Wood Composites as an Engineering Material, Use Recycl. Wood Pap. Build. Appl. Proc. a 1996 Symp. Spons. by U.S. Dep. Agric. For. Serv. For. Prod. Lab. For. Prod. Soc. Coop. with Natl. Assoc. (1997) 84-91. http://www.fpl.fs.fed.us/products/publications/specific_pub. php?posting_id=15782\&header_id=p.

[7] G.C.H. Doudart de la Grée, Q.L. Yu, H.J.H. Brouwers, Wood - wool cement board: optimized inorganic coating, Int. Inorg. Bond. Fibres Composites Conf. (2013).

[8] B. Na, Z. Wang, H. Wang, X. Lu, Wood-cement compatibility review, Wood Res. 59 (2014) 813-826.

[9] A.A. Moslemi, Y.T. Lim, Compatibility of southern hardwoods with Portland cement, For. Prod. J. (1984). 
[10] K. Kochova, K. Schollbach, F. Gauvin, H.J.H. Brouwers, Effect of saccharides on the hydration of ordinary Portland cement, Constr. Build. Mater. 150 (2017) 268-275, https://doi.org/10.1016/j.conbuildmat.2017.05.149.

[11] Simatupang, Geimer, Inorganic binder for wood composites: feasibility and limitations, 1990

[12] J.L. Pehanich, P.R. Blankenhorn, M.R. Silsbee, Wood fiber surface treatment level effects on selected mechanical properties of wood fiber-cement composites, Cem. Concr. Res. (2004), https://doi.org/10.1016/S0008-8846(03) 00193-5.

[13] E. Johansson, Woodwool Slabs-Manufacture, Properties and Use, n.d.

[14] R.S.P. Coutts, P. Kightly, Bonding in wood fibre-cement composites, 1984 https://link.springer.com/content/pdf/10.1007\%2FBF00549827.pdf (accessed 16.02.19.).

[15] A.A. Moslemi, S.C. Pfister, The influence of cement wood ratio and cement type on bending strength and dimensional stability of wood-cement composite panels, Wood Fiber Sci. 19 (1987) 165-175.

[16] H. Chen, M. Miao, X. Ding, Influence of moisture absorption on the interfacial strength of bamboo/vinyl ester composites, Compos. Part A Appl. Sci. Manuf. (2009), https://doi.org/10.1016/j.compositesa.2009.09.003.

[17] D.P. Miller, A.A. Moslemi, Wood-cement composites: effects of model compounds on hydration characteristics and tensile strength, For. Prod. J. 41 (1991) 9-14.

[18] BS EN 12089, Thermal insulating products for building applications. Determination of bending behaviour, 2013.

[19] S.a. Pasca, I.D. Hartley, M.E. Reid, R.W. Thring, Evaluation of Compatibility between Beetle-Killed Lodgepole Pine (Pinus Contorta var. Latifolia) Wood with Portland Cement, Materials (Basel) 3 (2010) 5311-5319, https://doi.org/ 10.3390/ma3125311.

[20] M. Hachmi, a.a. Moslemi, a.G. Campbell, A new technique to classify the compatibility of wood with cement, Wood Sci. Technol. 24 (1990) 345-354, https://doi.org/10.1007/BF00227055.
[21] A. Sundberg, K. Sundberg, C. Lillandt, B. Holmbom, Determination of hemicelluloses and pectins in wood and pulp fibres by acid methanolysis and gaschromatography, 1996, 216-219.

[22] E.N. Bs 13168, Thermal insulation products for buildings. Factory made wood wool (WW) products Specification, 2012

[23] L. Morawski, Plastics engineering, Imagine 6 (1999) 5-6, https://doi.org/ 10.1353/imag.2003.0244.

[24] J.A. Nairn, A numerical study of the transverse modulus of wood as a function of grain orientation and properties, Holzforschung. 61 (2007) 406-413, https://doi.org/10.1515/HF.2007.079.

[25] M. Gindl, G. Sinn, S.E. Stanzl-Tschegg, The effects of ultraviolet light exposure on the wetting properties of wood, J. Adhes. Sci. Technol. 20 (2006) 817-828, https://doi.org/10.1163/156856106777638653.

[26] S. Durmaz, Ö. Özgenç, I.H. Boyaci, Ü.C. YIldIz, E. Erişir, Examination of the chemical changes in spruce wood degraded by brown-rot fungi using FT-IR and FT-Raman spectroscopy, Vib. Spectrosc. 85 (2016) 202-207, https://doi. org/10.1016/j.vibspec.2016.04.020.

[27] D. Tamburini, C.R. Cartwright, G. Cofta, M. Zborowska, M. Mamoňová, Distinguishing the signs of fungal and burial-induced degradation in waterlogged wood from Biskupin (Poland) by scanning electron microscopy, Microsc. Microanal. 24 (2018) 163-182, https://doi.org/10.1017/ S143192761800020X.

[28] K.H. Kim, I.Y. Eom, S.M. Lee, S.T. Cho, I.G. Choi, J.W. Choi, Applicability of suband supercritical water hydrolysis of woody biomass to produce monomeric sugars for cellulosic bioethanol fermentation, J. Ind. Eng. Chem. 16 (2010) 918-922, https://doi.org/10.1016/j.jiec.2010.09.010.

[29] N.B. Milestone, The effect of glucose and some glucose oxidation products on the hydration of tricalcium aluminate, Cem. Concr. Res. 7 (1977) 45-52.

[30] D.M. Vasudevan, S. Sreekumari, K. Vaidyanathan, Textbook of Biochemistry for Medical Students, 2013, 78. https://books.google.com/books?id= nQz8AAAAQBAJ\&pgis $=1$. 